\title{
Yersinia outer-membrane protein B (YopB): a tool for identification of Yersinia pestis isolates
}

Yersiniae that are pathogenic to humans include Yersinia pestis, Yersinia pseudotuberculosis and Yersinia enterocolitica. $Y$. pestis is the cause of bubonic plague, which is transmitted by fleas. Common to all of these species is the presence of a $70 \mathrm{~kb}$ virulence plasmid that harbours a type III secretion system, and several secreted and translocated proteins called Yersinia outer proteins or Yops (Cornelis, 2002). The plasmid-encoded type III secretion system enables yersiniae to survive and proliferate extracellularly in host lymphatic tissues (Trülzsch et al., 2004). Three of the Yops - YopB, YopD and $\mathrm{LcrV}$ - are required for translocation of the others across the target-cell membrane (Viboud et al., 2003). The hydrophobic YopB and YopD thus seem to be central for translocation of the effectors and for the formation of a channel in lipid membranes. Presumably they play different roles in pore formation (Cornelis, 2000). Indeed, YopB alone can disturb artificial membranes, whereas YopD cannot (Francis \& Wolf-Watz, 1998). Accurate laboratory identification guarantees the safe control and handling of specimens and is essential for surveillance of the spread of $Y$. pestis in natural plague foci (Anisimov et al., 2004). The present study was aimed at developing a $Y$. pestis-specific PCR for the $y o p B$ gene and a specific immunoassay for detection or typing of $Y$. pestis strains. The isolates used to characterize these assays were from human patients and rodent samples from 1994 outbreak regions (Batra et al., 1996), and from surveillance studies of the Deccan plateau region (U. Tuteja, J. Shukla \& H. V. Batra, unpublished data) (Table 1). Plasmid DNA was extracted from cultures by alkaline lysis (Maniatis et al., 1982). The entire $70 \mathrm{~kb} /$ low-calcium response locus plasmid sequence (GenBank accession no. AF074612) was used to design $Y$. pestis-specific primers for the yopB gene using DNASIS software. The primer sequences were 5' -AAAAATGGCGGGGTGAGTT-3' (forward) and 5'-AAAACTCGGCTCCTTTAGC-3' (reverse). PCR amplification was carried out in a $50 \mu \mathrm{l}$ reaction mixture containing the extracted bacterial plasmid $(50 \mathrm{ng})$ isolated from the $Y$. pestis isolates and standard strains, $200 \mu \mathrm{M}$ each dNTP, $1 \mu \mathrm{M}$ each primer, $1 \mathrm{U}$ Taq polymerase and $10 \times$ buffer (Qiagen) using a Perkin Elmer model 480 thermal cycler. Amplification consisted of 30 cycles of $94^{\circ} \mathrm{C}$ for $1 \mathrm{~min}$, $48^{\circ} \mathrm{C}$ for $1 \mathrm{~min}$ and $72^{\circ} \mathrm{C}$ for $2 \mathrm{~min}$. PCR products were analysed on a $1.5 \%$ agarose gel (Fig. 1). The yopB gene 700 bp amplicon was detected from standard Y. pestis A1122, but other Yersinia (Fig. 1) and non-Yersinia (not shown) species were negative. All 18 isolates from human and rodent samples from outbreak regions were able to produce the 700 bp amplification product, while two of the isolates from rodents from the surveillance region were negative for the yopB gene (Table 1). The 700 bp PCR product was cloned into the $\mathrm{PQE}-32$ expression vector by ligation using SmaI and Klenow fragment blunt-ended DNA, and transformed into Escherichia coli SG13009 cells (Sambrook et al., 1989). Recombinant clones were confirmed by restriction analysis and PCR (using SmaI and the same primers as above) (not shown). Expression of recombinant YopB protein was obtained by inoculating cultures, growing them overnight in LB broth and then inducing expression with $1 \mathrm{mM}$ IPTG. Whole-cell lysates of the bacteria were prepared and expression of the recombinant protein was examined by $10 \%$ SDS-PAGE (Laemmli, 1970). Recombinant protein was purified by Ni-NTA affinity chromatography (Qiagen). The truncated recombinant YopB (rYopB) protein obtained was estimated to be $28 \mathrm{kDa}$ by SDS-PAGE and the concentration of the protein was $4 \mathrm{mg} \mathrm{ml}^{-1}$ by the Lowry method. To characterize the recombinant protein and develop an antigen-based immunoassay, rabbits (for polyclonal antibodies) and $\mathrm{BALB} / \mathrm{c}$ mice (for mAbs) were immunized with four doses of 500 and $50 \mu \mathrm{g}$ recombinant protein, respectively. Total

Table 1. $Y$. pestis isolates, their origin, and the results of PCR, dot-ELISA and Western blotting

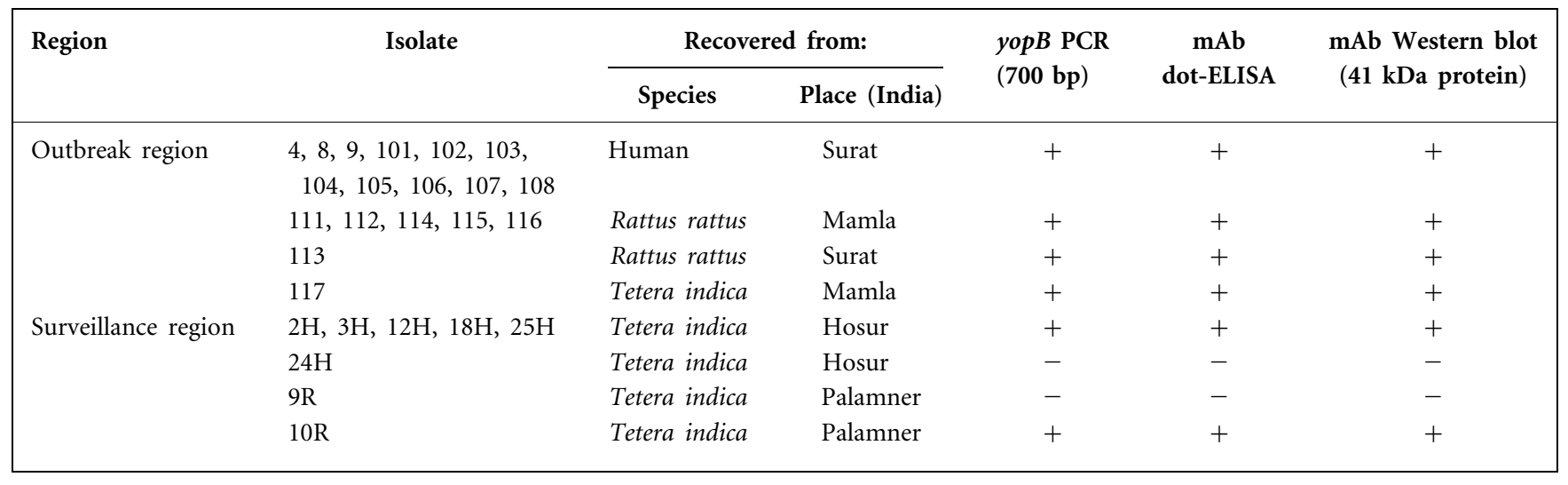




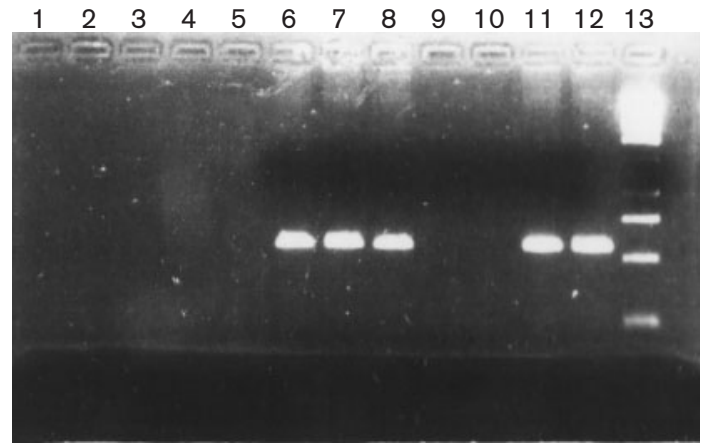

Fig. 1. $P C R$ amplification of the $y o p B$ gene in $Y$. pestis isolates. Lanes: $1, Y$. kristensenii; 2, Y. intermedia; 3, Y. fredericksenii; 4, Y. enterocolitica; 5, Y. pseudotuberculosis; $6-11, Y$. pestis isolates $(112,111,10 \mathrm{R}, 9 \mathrm{R}, 24 \mathrm{H}$ and 8$) ; 12$, standard $Y$. pestis A1122; 13, molecular mass marker (200 bp step ladder). immunoglobulin serum antibody titres were determined 7 days after the last booster by dot-ELISA (Khushiramani et al., 2004). After the fourth dose, rabbit and mice antibody titres were determined as 1:64 000 by dot-ELISA. The hyperimmune sera were used in Western blotting (Towbin et al., 1979) to check their reactivity against the native $Y$. pestis Yop proteins and the recombinant protein. Rabbit polyclonal antibodies raised against rYop detected bands of $28 \mathrm{kDa}$ in cell lysates from IPTG-induced recombinant E. coliSG13009 and $41 \mathrm{kDa}$ for native antigens of $Y$. pestis (Fig. 2). This finding suggested that the antigenicity of the recombinant protein was maintained. In another study, the same recombinant protein was also found to be biologically active. Both the truncated rYopB and $\mathrm{rLcrV}$ in the in vitro studies inhibited LPS-induced tumour necrosis factor- $\alpha$, gamma interferon, keratinocyte-derived chemokine, IP-10, interleukin 12 and NO production in murine peritoneal macrophages (Sharma et al., 2004; Sodhi et al., 2004).

To check variation at the epitope level, mAbs were prepared following a standard PEG fusion protocol (Köhler \& Milstein, 1975). mAbs produced by the hybridoma were screened by dot-ELISA. A total of ten stable mAbs was obtained against truncated rYopB protein. The class of immunoglobulin was determined by dot-ELISA using a mouse Typer isotyping kit (Bio-Rad). One of the clones was IgM type, whilst the rest were IgG type (subtypes IgG1, IgG2a, IgG2b, IgG3 and IgG4) having lambda and kappa light chains. The mAbs generated were tested for specificity using Y. pestis A1122, Y. pseudotuberculosis 1A, $Y$. enterocolitica strain $\mathrm{O}: 8$, Yersinia kristensenii, Yersinia fredericksenii, Yersinia intermedia, E. coli, Salmonella typhi, Staphylococcus aureus, 'Salmonella abortus' and Klebsiella pneumoniae strains in dot-ELISA and Western blotting. In another study, it was observed that interaction of YopB with the host cell triggered a pro-inflammatory signalling response that was counteracted by multiple effectors in the host cell (Viboud et al., 2003). The YopB protein expressed in the present study could be used to enhance the immune response in eukaryotic cells. All clones were specific to $Y$. pestis when tested against other Yersinia and non-Yersinia species by dot-ELISA. Western blot reactions with mAbs to recombinant proteins were observed at the expected size of $41 \mathrm{kDa}$ for the YopB protein of standard Y. pestis A1122 and isolates. The results obtained with $\mathrm{mAb}$-based immunoassays correlated fully with the PCR results when tested with all of the Indian isolates (Table 1). mAbs generated in the present study could be utilized to study the exact mechanism of action of YopB proteins and their receptors. As these mAbs are specific to $Y$. pestis and as variation in the yopB gene of isolates was also observed, this PCR and immunoassay could be used as simple, rapid and cost-effective methods for the typing of $Y$. pestis strains.

\section{Acknowledgements}

The authors are grateful to Dr R. V. Swamy, ex-Chief Controller (R \& D), DRDO, New Delhi, India, for encouragement to conduct the study.

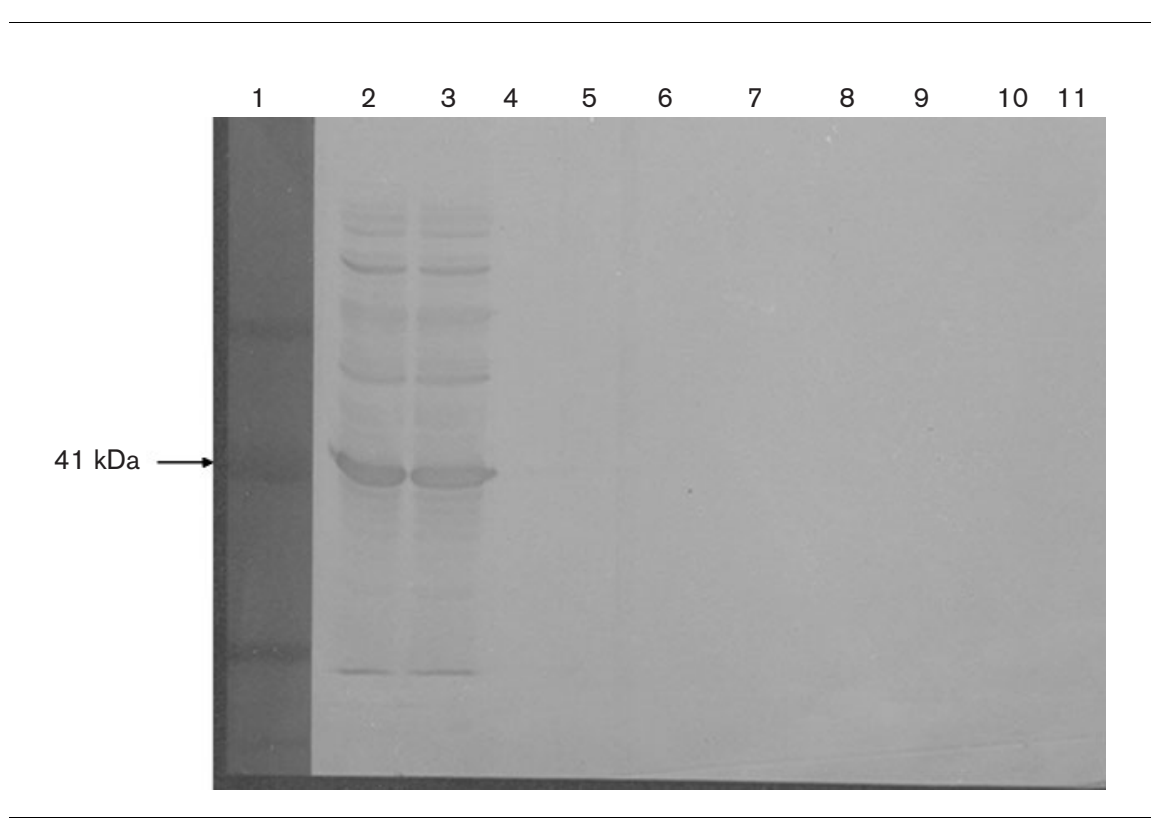

Fig. 2. Reactivity of polyclonal antibody. Lanes: 1, molecular mass marker (PMW-M, 14.3-97.4 kDa; Bangalore Genei); 2, standard $Y$. pestis A1122; 3, Y. pestis isolate recovered from a human patient from a plague outbreak; 4 and $5, Y$. pestis isolates (9R and $24 \mathrm{H}$ ) recovered from rodents from surveillance regions; 6 , standard $Y$. pseudotuberculosis 1A; 7, Y. enterocolitica; 8, Y. intermedia; 9, Y. fredericksenii; 10, Y. kristensenii; 11 , E. coli. 


\section{Rekha Khushiramani, Jyoti Shukla, Urmil Tuteja and Harsh Vardhan Batra}

\section{Division of Microbiology, Defence}

Research and Development Organisation (DRDO), Jhansi Road, Gwalior 474 002, India

Correspondence: Harsh Vardhan Batra (h_v_batra@rediffmail.com)

Anisimov, A. P., Lindler, L. E. \& Pier, G. B. (2004). Intraspecific diversity of Yersinia pestis. Clin Microb Rev 17, 434-464.

Batra, H. V., Tuteja, U. \& Agarwal, G. S. (1996). Isolation and identification of Yersinia pestis responsible for the recent plague outbreaks in India. Curr Sci 71, 787-791.

Cornelis, G. R. (2000). Molecular and cell biology aspects of plague. Proc Natl Acad Sci U S A 97, 8778-8783.

Cornelis, G. R. (2002). The Yersinia Ysc-Yop 'type III' weaponry. Nat Rev Mol Cell Biol 3, 742-752.

Francis, M. S. \& Wolf-Watz, H. (1998). YopD of Yersinia pseudotuberculosis is translocated into the cytosol of HeLa epithelial cells: evidence of a structural domain necessary for translocation. Mol Microbiol 29, 799-813.

Khushiramani, R., Tuteja, U., Shukla, J. \& Batra, H. V. (2004). Characterization of outer membrane proteins of Yersinia pestis and Yersinia pseudotuberculosis strains isolated from India. Ind J Exp Biol 42, 508-514.

Köhler, G. \& Milstein, C. (1975). Continuous cultures of fused cells secreting antibody of predefined specificity. Nature 256, 495-497.

Laemmli, U. K. (1970). Cleavage of structural proteins during the assembly of the head of bacteriophage T4. Nature 227, 680-685.

Maniatis, T., Fritsch, E. F. \& Sambrook, J. (1982). Molecular Cloning: a Laboratory Manual. Cold Spring Harbor, NY: Cold Spring Harbor Laboratory.

Sambrook, J., Fritsch, E. F. \& Maniatis, T. (1989). Molecular Cloning: a Laboratory Manual, 2nd edn. Cold Spring Harbor, NY: Cold Spring Harbor Laboratory.

Sharma, R. K., Sodhi, A., Batra, H. \& Tuteja, U. (2004). Effect of rLcrV and rYopB from
Yersinia pestis on murine peritoneal macrophages in vitro. Immunol Lett 93, 179-187.

Sodhi, A., Sharma, R. K., Batra, H. V. \& Tuteja, U. (2004). Mechanism of rLcrV and rYopB mediated immunosuppression in murine peritoneal macrophages. Mol Immun 41, 767-774.

Towbin, H., Staehelin, T. \& Gordon, J. (1979). Electrophoretic transfer of proteins from polyacrylamide gels to nitrocellulose sheets; procedures and some applications. Proc Natl Acad Sci U S A 76, 4350-4354.

Trülzsch, K., Sporleder, T., Igwe, I. E., Rüssmann, H. \& Heesemann, J. (2004). Contribution of the major secreted Yops of Yersinia enterocolitica $\mathrm{O}: 8$ to pathogenicity in the mouse infection model. Infect Immun 72, 5227-5234.

Viboud, G. I., So, S. S. K., Ryndak, M. B. \& Bliska, J. B. (2003). Proinflammatory signaling stimulated by the type III translocation factor YopB is counteracted by multiple effectors in epithelial cells infected with Yersinia pseudotuberculosis. Mol Microbiol 47, 1305-1315. 